Darja Zorko

Mencin

SKB banka, $d$. $d$.

\title{
Kvalitativni vidiki ponudbe jezikovnih tečajev v Sloveniji - kako izbrati
}

aradi večje odprtosti družbe in mednarodnih povezav, deleža tujih podjetij in kapitala pomembnost dobrega znanja tujih jezikov pri poslovnem in osebnem uspehu vse bolj narašča. Izobraževalne institucije imajo velike možnosti za razvoj, znanje tujih jezikov odpira vrata $\mathrm{v}$ svet in njihovo obvladovanje je neizogibno, če se hočemo pripraviti na nove poslovne izzive na svetovnem trgu.

Prispevek obravnava kvalitativne vidike ponudbe pri učenju tujih jezikov v Sloveniji. Primerjalna analiza ponudbe kaže na njeno organiziranost in širši pomen, ki ga ima tovrstno izobraževanje. Očitne so številne podobnosti in razlike, gre torej za odprti trg številnih ponudnikov, ki so neodvisni tržni subjekti in poslujejo le s prodajo lastnih storitev. Priča smo hitremu preskoku v delovanju in načinu poslovanja, usmerjenemu k zavedanju o pomenu kakovosti storitev in dovzetnosti za novosti z upoštevanjem potreb uporabnikov.

Podjetja poudarjajo predvsem koristi, ki jih lahko pričakujejo ob vključitvi v njihove programe. Poslanstvo izvajalcev pa je pripeljati udeležence po najkrajši poti do solidnega znanja in pridobiti zaupanje tečajnikov. Precej odraslih je v nasprotju s tem prepričanih, da je učenje tujih jezikov dolgotrajen in pogosto mučen proces. V zadnjih letih smo pri poučevanju tujih jezikov priča velikemu koraku naprej s kvalitativnega vidika, kar je posledica drugačnih metod učenja in prenovljene vsebine programov. Zagotavljanje kvalitete storitev je zelo pomembno za pridobivanje in ohranjanje tržnega deleža. Cilj večine izvajalcev je kvaliteta programov, in ne množičnost. Utrjevanje ugleda izobraževalnih institucij je ob veliki konkurenci izjemno pomembno. Izvajalci upoštevajo andragoška spoznanja in dejstvo, da se odrasli učijo tujega jezika učinkoviteje, če se učijo na sebi »primeren« način.

\section{PONUDNIKI}

Izobraževalne institucije so organizirane kot ljudske univerze, izobraževalni centri, jezikovne šole, javni in zasebni zavodi, podjetja, povečuje pa se tudi število samostojnih podjetnikov. Nekatere tovrstne institucije, kot so ljudske univerze, imajo že tradicijo in dolgo zgodovino delovanja. Precejšen je tudi delež tistih, ki svojo dejavnost izvajajo manj kot deset let. Če primerjamo dejavnost, lahko opazimo veliko pestrost, saj se poleg poučevanja odraslih ukvarjajo tudi s poučevanjem otrok in mladine ter prevajanjem. Pri ljudskih univerzah je jezikovno izobraževanje samo manjši del ponudbe, ker se ukvarjajo predvsem s splošnim in poklicnim izobraževanjem ter $\mathrm{z}$ izobraževanjem na področju poslovnih ved. Katalog Izobraževanje odraslih v Sloveniji, Izvajalci in programi 2000/2001, ki ga je izdal Andragoški center Slovenije, predstavlja več kot 260 tovrstnih institucij. $\mathrm{Na}$ internetu je mogoče dobiti podatke o velikem številu izvajalcev, ki predstavljajo ponudbo in navajajo vrste tečajev, ki jih izvajajo. 
$\mathrm{Na}$ trgu izobraževalnih storitev imajo pomembno vlogo tudi izobraževalne institucije, ki delujejo na področju poslovnih ved, občasno pa organizirajo specializirane seminarje in tečaje tujih jezikov.

Če primerjamo ponudbo jezikovnega izobraževanja, lahko opazimo, da institucije delujejo v vseh regijah. Glede na število lahko sklepamo, da je največ ponudnikov v Ljubljani.

\section{UDELEŽZNCI}

Podjetja namenjajo posebno pozornost vpisu novih udeležencev. Poleg znanja, ki ga preverjajo s testi, skrbno preučijo tudi raznolikost potreb, interesov ter pričakovanja udeležencev in jih primerjajo $\mathrm{z}$ izobraževalnimi cilji posameznih programov. Pomembno je, da se ugotovi, kakšno znanje udeleženci potrebujejo, zakaj, kdaj in kje bodo pridobljeno znanje uporabljali.

Ko govorimo o udeležencih, je pomembno, da se izvajalci zavedajo, da je treba željam in zahtevam udeležencev čimbolj ustreči. Kajti na osnovi izkušenj udeleženci oblikujejo svoje zadovoljstvo oziroma nezadovoljstvo s storitvijo.

Potrebe in interesi udeležencev po znanju tujega jezika izhajajo iz konkretnih življenjskih okoliščin, potreb delovnega procesa in pogostosti uporabe jezika. Pred leti so se za izobraževanje tujih jezikov odločali udeleženci predvsem na osnovi lastnega interesa in brez potrebe po uporabi tega znanja v praksi. Pridobljeno znanje ponavadi ni bilo preverjeno $\mathrm{v}$ praksi. Danes podjetja prijavljajo samo tiste udeležence, pri katerih izhaja potreba po znanju določenega jezika iz zahtev delovnega procesa in dejanskega komuniciranja $v$ tujem jeziku. Intenzivnost se poveča, kadar podjetja dobijo tuje lastnike in partnerje ali pa so vključena v mednarodne projekte.

\section{PREDAVATELJI}

Strokovnost učiteljev mora biti na visoki ravni, saj je to temelj, na katerem upravičujejo šole svojo kvaliteto. Praksa kaže, da je vloga učiteljev in mentorjev pri organiziranju in izvajanju poučevanja tujih jezikov nadvse pomembna, kajti oni so tisti, ki skušajo na najprimernejši način posredovati izobraževalno storitev udeležencem. Vse več je jezikovnih šol, ki v prospektih predstavljajo svoje sodelavce in njihove uspehe pri poučevanju. Dobro poznavanje stroke, mednarodno priznani certifikati, diplome in izkušnje pri poučevanju doma ter $\mathrm{v}$ tujini $\mathrm{v}$ praksi pogosto niso dovolj. Za uspešno delo so potrebne lastnosti, ki naj bi jih imeli profesorji: dinamičnost, sposobnost motiviranja udeležencev, predanost in veselje do poučevanja. Število redno zaposlenih je odvisno od velikosti izobraževalnih institucij. Čeprav večina manjših jezikovnih šol nima redno zaposlenih učiteljev, je opaziti, da si šole prizadevajo, da bi pridobile kvalitetne in izkušene učielje. Sodelovanje poteka na osnovi honorarnega sodelovanja, ki pa predavateljem ne omogoča zaposlitvene varnosti. Povečuje se delež učiteljev, ki hkrati poučujejo pri več institucijah. Pri višjih stopnjah učenja tujih jezikov pouk izvajajo tako imenovani »native speakerji«, ki še dodatno pripomorejo $\mathrm{k}$ učinkovitosti učenja. $\mathrm{V}$ jezikovnih šolah ugotavljajo, da je kombinacija »domačega učitelja in »native speakerja《 zelo učinkovita, ker $\mathrm{v}$ programu dopolnjujeta svoji vlogi. Kvalitetne izobraževalne institucije se zavedajo potrebe po dolgoročnem razvoju in vlagajo $\mathrm{v}$ razvoj strokovnosti učiteljev. Zato morajo pripravljati interne oblike usposabljanja, da so učitelji seznanjeni z novostmi $\mathrm{v}$ zvezi s tehnikami in metodami na področju izobraževanja in tujih jezikov. Vodje posameznih področij nadzorujejo pripravo in izvedbo programov. Čedalje več šol dobiva povratne informacije z različnimi vprašalniki, ki jih izpolnjujejo udeleženci in na podlagi katerih 
lahko izobraževalna institucija izboljša svoje delo. Ocenjevanje kvalitete izvajalcev je sestavni del pouka, pri čemer udeleženci ocenjujejo lastnosti in vedenje učiteljev: natančnost, poznavanje snovi, strukturo ur, sposobnost prisluhniti potrebam posameznikov in prilagajanje skupini.

\section{UČNO GRADIVO IN METODE}

Storitev učenja tujih jezikov je izobraževalni program, ki je za nekatere stopnje bolj ali manj določen in skupen vsem šolam. Učno gradivo sestavljajo knjige, avdio in video kasete, računalniški programi, zbirke vaj. $\mathrm{Na}$ željo naročnika uporabljajo izvajalci pri pouku tudi naročnikove dokumente in gradivo. Glede na potrebe udeležencev predavatelji pripravijo dodatno gradivo kot dopolnilo $\mathrm{k}$

Vse več je

povprasevanja po individualnih

izobraževalnih programih. osnovnemu gradivu (članki, poslovna besedila, referati).

Šole pripravljajo lastne učne programe in razvijajo alternativne sodobne metode poučevanja. Najbolj znana je Berlitz, ki je direktna in pri kateri pouk poteka ves čas le v ciljnem jeziku brez prevajanja. Učitelji so »native speakers«, ki poučujejo svoj materni jezik in so usposobljeni za uporabo metode.

Šole pri pouku ponavadi uporabljajo kombinirane didaktične metode, ki vsebujejo te elemente: »mind mapping « (miselni vzorci) in asociacije, »superlearning « (učenje ob prijetni glasbi), moderacija, vizualizacija, igranje vlog, dramatizacija, metoda primera, delo $\mathrm{v}$ skupinah, uporaba stenskih panojev in slik.

\section{PONUDBA}

Če primerjamo ponudbe izvajalcev, lahko opazimo težnjo po individualizaciji pri realizaciji učnih ciljev. Večina programov je prenovljenih v skladu z evropskimi standardi in priporočili Sveta Evrope. Zanimivo je, da se je možno učiti različnih jezikov, v Sloveniji prevladuje učenje angleščine, nemščine in francoščine.

Izvajalci so časovno vse fleksibilnejši, urnik se prilagaja glede na potrebe udeležencev. Možno se je učiti zjutraj, popoldne ali zvečer. Udeleženci izberejo intenzivnost učenja, saj tečaji potekajo dvakrat ali trikrat na teden $\mathrm{z}$ različnim številom ur (od dveh do štirih pedagoških ur skupaj). Pri intenzivnih tečajih poteka učenje ves dan. Gre za redne ali občasne seminarje, delavnice, posvete, krožke, neformalna mesečna srečanja. Najpogostejše vrste tečajev so začetni, nadaljevalni, osvežitveni, poslovni tečaji, ki obravnavajo strokovno terminologijo, komunikacijski tečaji, tečaji, na katerih se udeleženci pripravljajo za mednarodni ali slovenski izpit o znanju tujih jezikov, specialni tečaji za posamezne poklicne skupine (na primer tajnice, bančniki, pravniki, pedagoški delavci), tečaji osebne in poslovne korespodence, tečaji v tujini.

Individualni tečaji, tečaji za intenzivne skupine in interni tečaji potekajo običajno vse leto, drugi tečaji za skupine pa po vnaprej razpisanem roku spomladi in jeseni. Učenje na daljavo se lahko začne vsak mesec, pri čemer pri samostojnem učenju občasno sodelujejo učitelji, dvakrat na mesec pa se udeleženci srečajo na komunikacijski delavnici.

$\mathrm{Za}$ vodilne kadre, ki se morajo v kratkem času naučiti tujih jezikov, so primerni enotedenski tečaji zunaj podjetij. Učenje poteka v skupini 3-15 udeležencev. Izobraževalni programi so pripravljeni tako, da pomagajo razvijati različne spretnosti: tekoče govorjenje in pravilno pisanje, bogatenje besednega zaklada in aktivno komuniciranje. Udeleženci uporabljajo avdio kasete in knjige $\mathrm{z}$ vajami, ki omogočajo redno utrjevanje in poglabljanje naučenega. Nova tehnologija in video učne ure pospešujejo napredek. »Lin- 
Zadnje čase se vse več udeležencev odloča za individualno učenje tujih jezikov $\mathrm{z}$ učiteljem ali pa za samostojno učenje na osnovi vnaprej pripravljenih programov na CD-ROM-ih. Povečuje se delež tistih, ki uporabljajo storitve središč za samostojno učenje. $\mathrm{Na}$ osnovi izkušenj so strokovnjaki prepričani, da je individualno učenje najhitrejša in najučinkovitejša pot do znanja tujih jezikov, saj zagotavlja optimalno rabo časa, denarja in energije.

guafon « je metoda učenja jezika po telefonu, ki poteka tako, da se udeleženec in učitelj pogovarjata in obdelujeta učno gradivo po telefonu. Dobre šole dopolnjujejo programe s sodelovanjem $\mathrm{z}$ domačimi in tujimi univerzitetnimi institucijami.

\section{CENA}

Cena izraža vrednost izobraževalnega programa $v$ denarju. Njena višina je odvisna od cene konkurentov za določen izobraževalni program, trenutnega povpraševanja in kupne moči udeležencev. Konkurenčno prednost imajo predvsem manjše zasebne šole in samostojni podjetniki, saj poslujejo $\mathrm{z}$ nizkimi režijskimi stroški. Najpogosteje dosežejo znižanje cen storitev $\mathrm{z}$ večjim obsegom poslovanja in znižanjem stroškov. Pri določitvi cene programov upoštevajo izvajalci dejanske stroške, dejavnike ponudbe ter povpraševanja in konkurenčne dejavnike. Pri tem ne smemo spregledati pomena cene za uporabnika. Cena programa namreč ni edini strošek, upoštevati je treba tudi stroške njegovega truda, časa in energije.

Večina izvajalcev ima cene določene glede na osnovno neto učno uro za zaključeno skupino, pri drugih se cene razlikujejo glede na število udeležencev. Cene so odvisne tudi od tega, kje izobraževanje poteka, cena je nižja, kadar poteka izobraževanje pri naročniku. $\mathrm{Na}$ osnovi primerjave cenikov lahko ugotovimo, da se med različnimi izvajalci cene razlikujejo za približno 15 odstotkov za zaključene skupine in individualno učenje. Nekatere institucije imajo cene fiksne ne glede na stopnjo učenja. Pri drugih pa se cene pedagoške ure razlikujejo glede na poslovni jezik ali zahtevnostno raven, pri splošnem jeziku in osnovnih stopnjah učenja so cene nižje za
Cenorno se ponudbe različnih izvajalcev razlikujejo za 15 odstokov. okoli 10 odstotkov. Cene so nižje pri nekaterih izvajalcih zunaj Ljubljane.

\section{KONKURENČNA PREDNOST}

Konkurenca med izvajalci poteka na več ravneh: udeleženci, kvalitetni predavatelji, finančna sredstva in ugodno javno mnenje. Uspešnost izobraževalnih institucij se ne meri s količino storitev, ampak s stopnjo zadovoljitve potreb uporabnikov. Izvajalci predstavljajo svojo prednost pred konkurenti $\mathrm{z}$ naslednjimi dejavniki:

- strokovnost in prijaznost učiteljev,

- učinkovite metode poučevanja, ki omogočajo hitrejši napredek,

- uporabnost znanja in posredovanje znanja za dejanske poslovne situacije,

- razumljiva razlaga,

- prilagodljivost programa glede na konkretne izobraževalne potrebe,

- velikost skupin in homogenost znanja udeležencev,

- sodobno urejeni prostori in dostopnost lokacije,

- javno veljavni programi,

- svetovanje glede ustreznega izobraževalnega programa,

- velikost in homogenost skupine,

- sodobni učni pripomočki in preizkušeni učbeniki, 
- sprotno preverjanje znanja, ki omogoča udeležencem, da sproti dobijo povratne informacije o napredovanju pri učenju, ciljno učenje povečuje motivacijo udeležencev.

Med tradicionalne ugodnosti spadajo popusti pri takojšnjem plačilu tečaja, možnost plačila na več obrokov in popusti za dijake ter študente.

Kadar podjetja prijavijo večje število udeležencev ali imajo več skupin, imajo poseben popust. Da bi izvajalci obdržali naročnike, ponujajo posebne popuste glede na dosedanje sodelovanje, da bi se prepričali o kvaliteti učenja, pa ponujajo brezplačne demostracijske ure pouka.

Izvajalci zagotavljajo tudi druge ugodnosti, na primer:

- popust ob vpisu v začetno stopnjo ali določen program;

- povrnitev stroškov, če udeleženec preneha obiskovati tečaj iz upravičenih razlogov;

- dodatni pouk in druge storitve (na primer prevajanje);

- popust za termine med 9.00 in 15.30 ;

- popust za samoplačnike;

- popust za udeleženca, ki pripelje novega udeleženca.

4,2001

Zanimive so tudi novosti, ki jih ponujajo v letošnjem jesenskem semestru:

- popestritev učenja z multimedijsko opremo, pri čemer poteka učenje $\mathrm{v}$ računalniških učilnicah;

- krajši jezikovni tečaji zunaj učilnic v vsakdanjih situacijah (na primer, v trgovini);

- darilni bon za jezikovno izobraževanje;

- jamstvo za uspešen zaključek tečajev, če udeleženci ne končajo tečaja uspešno, imajo pravico do brezplačnega vpisa v tečaj ali pa mu denar vrnejo;

- video konference;

- jezikovna pomoč prek interneta;

- slovar najpogostejših strokovnih terminov.

\section{TRŽENJE}

Izobraževalne institucije upoštevajo spoznanje, da so najboljša trženjska poteza in referenca zadovoljni udeleženci, zato še posebej skrbno negujejo odnose z njimi. Trženjska aktivnost zajema raziskovanje in sistematično predvidevanje potreb, želja in zahtev udeležencev in drugih naročnikov.

Zaradi velike konkurence med izvajalci prihajajo v ospredje trženjski vidiki ponudbe, ki kažejo na programsko in organizacijsko usmerjenost. Za povečanje tržnega deleža se odločajo za intenzivno trženje, imajo različne predstavitve programov, na primer dan odprtih vrat. V predstavitvenih dokumentih je opaziti, da se povečuje delež tistih, ki navajajo svoje reference, naštevajo podjetja in mnenja udeležencev, ki so bili vključeni v izobraževanje. V okviru odnosov z javnostmi objavljajo izjave managerjev podjetij, ki poudarjajo uspešnost sodelovanja. Priporočila imajo lahko pomembno vlogo pri pridobivanju novih udeležencev, še posebej nezaupljivih.

Nekatere institucije ne namenjajo trženju posebne pozornosti, saj njihovo delovanje temelji na sedanjih udeležencih in ne vidijo prednosti v predstavljanju svojih storitev.

Kakovost učenja tujih jezikov se lahko doseže samo, če je zagotovljeno usklajeno delovanje vseh akterjev v izobraževalnem procesu. Kot strokovni izziv na koncu postavljamo vprašanje, kako doseči učinkovitost učenja tujih jezikov glede na različnost izobraževalnih ciljev.

\section{VIRI}

Izobraževanje odraslih v Sloveniji, Izvajalci in programi 2000/2001.

Različne vrste ponudb (v oglasih v časopisih, ponudbe za podjetja, predstavitev izvajalcev poučevanja tujih jezikov na internetu). 